\title{
Hyaluronidase enhances the activity of Adriamycin in breast cancer models in vitro and in vivo*
}

\author{
Karin Beckenlehner ${ }^{1}$, Silke Bannke ${ }^{1}$, Thilo Spruß ${ }^{1}$, Günther Bernhardt ${ }^{1}$, \\ Helmut Schönenberger ${ }^{1}$, and Wilfried Schiess ${ }^{2}$ \\ 1 Institut für Pharmazie, Universität Regensburg, Universitätsstr. 31, W-8400 Regensburg, Federal Republic of Germany \\ 2 Sandoz Gesellschaft m.b.H., Brunnerstr. 59, A-1235 Wien, Austria \\ Received 27 January 1992/Accepted 4 May 1992
}

\begin{abstract}
Summary. The effect of hyaluronidase and a combination of hyaluronidase with Adriamycin was investigated on several breast cancer models in vitro and in vivo. In vitro enzyme treatment (using concentrations up to $80000 \mathrm{IU} /$ 1) of murine (MXT ${ }^{-}, \mathrm{MXT}^{ \pm}$, and $\left.\mathrm{MXT}^{+}\right)$and human (MCF-7, ZR-75-1 and T-47-D) breast cancer cell lines did not inhibit tumour cell proliferation (measured by a kinetic crystal violet assay) in either case. Although highdose hyaluronidase $\left(1.2 \times 10^{6} \mathrm{IU} / \mathrm{kg}\right)$ was ineffective, when administered peritumourally to the MXT M3.2 mammary carcinoma of the $\mathrm{B} 6 \mathrm{D} 2 \mathrm{~F}_{1}$ mouse, it is remarkable that five "megadoses" were excellently tolerated. However, the antineoplastic activity of Adriamycin against the oestrogen-receptor-positive variant of the MXT tumour was significantly enhanced by combination with concentrations of hyaluronidase that were inactive per se, both in vitro and in vivo. Interestingly, the enhancement of the in vivo antitumour activity was not compromised by toxic side-effects.
\end{abstract}

Key words: Hyaluronidase - Adriamycin - Breast cancer models - Enhancement of antitumour activity - No toxic side-effects

\section{Introduction}

Whereas numerous studies have confirmed the diagnostic value of elevated serum levels of hyaluronic acid associated with malignant mesothelioma (Frebourg et al. 1987; Pettersson et al. 1988; Dahl et al. 1989) and Wilms' nephroblastoma (Wu et al. 1984; Stern et al. 1991), there have been few reports of raised serum levels in other types of advanced cancer (Delpech et al. 1985; Dahl and Laurant 1988). Cooper and Forbes (1988) presented data on the distribution of serum hyaluronic acid in patients with

\footnotetext{
* Dedicated to Professor Wolfgang Wiegrebe on the occasion of his 60 th birthday

Correspondence to: $\mathrm{G}$. Bernhardt
}

metastatic cancer or large local tumours (myeloma, melanoma, sarcoma, cancer of the pancreas, stomach, colon, lung - small cell and non-small cell, prostate, ovary and breast). Within each type of cancer individual patients showed strongly elevated levels of hyaluronic acid, but statistically significant, overall increased levels were only present in pancreatic cancer, small-cell lung cancer and carcinoma of the prostate.

Although increased synthesis of glycosaminoglycans is not a universal characteristic of tumours, it seems likely that hyaluronic acid production plays an important role in tumour cell proliferation, differentiation, invasion and metastasis (Knudson et al. 1989). In this context, hyaluronan has been implicated in the pathology of experimental and human breast cancer (Angello et al. 1982; Kimata et al. 1983; Marotta et al. 1985; Knudson et al. 1989; Decker et al. 1989; Prehm 1990).

Therefore, it is conceivable that breast cancer might be an indication for the therapeutic application of hyaluronidase, an enzyme cleaving hyaluronic acid. Hyaluronidase has for some time been used as an additive to chemotherapy in several studies (Baumgartner 1988) including a phase I trial (Baumgartner et al. 1988).

The pharmacology of hyaluronidase and its potential role in the treatment of malignant disease has been reviewed recently (Baumgartner 1987; Baumgartner and Moritz 1988). Although the clinical trials have shown encouraging but not definite indications of possible augmentation of the antitumour activity of the chemotherapeutics used after preinfusion of hyaluronidase, to date most of the evidence is "pilot" in nature.

In addition, preclinical data obtained in cell culture (Liu et al. 1987; Kohno et al. 1988; Scheithauer et al. 1988; Lehnert et al. 1989) and experimental rodent tumour models (Seipelt and Kohlheb 1967; Pawlowski et al. 1979; Sargent et al. 1983) are scanty and inconsistent.

As a first approach to characterize the potential efficacy of hyaluronidase in the therapy of breast cancer, we systematically assayed the in vitro chemosensitivity of various murine $\left(\mathrm{MXT}^{-}, \mathrm{MXT}^{+}, \mathrm{MXT}^{ \pm}\right)$and human 
(MCF-7, T-47-D, ZR-75-1) breast cancer cell lines against increasing concentrations of hyaluronidase. As an extension of these experiments, the antitumour activity of hyaluronidase was tested in vivo, using the syngenic MXT M3.2 mammary carcinoma of the B6D2 $\mathrm{F}_{1}$ mouse. Further studies using the same model clearly demonstrated that hyaluronidase combined with Adriamycin significantly enhanced the antineoplastic effect of the anthracycline, both in vitro and in vivo.

\section{Materials and methods}

Chemicals. Reagents (A-grade purity) were obtained from Merck (Darmstadt, FRG). $\mathrm{N}$-Hexamethylpararosaniline (crystal violet) was purchased from Serva (Heidelberg, FRG). All culture media were from Sigma (München, FRG), and fetal calf serum (FCS) was from Gibco (Eggenheim, FRG). Millipore-filtered water was used throughout.

Cell lines and routine culture conditions. The murine cell lines used in the in vitro studies were established from different variants of the MXT mammary carcinoma of the B6D2F mouse (Beckenlehner 1991). The human breast cancer cell lines (MCF-7, T-47-D and ZR75-1) were obtained from the American Type Culture Collection (Rockeville, Md., USA). Cell line banking and quality control were performed according to the "seed stock concept" reviewed by Hay (1988).

Proliferation kinetics, karyology, and hormone receptor content of the human breast cancer cell lines used in our laboratory have been described elsewhere (Bernhardt et al. 1992).

MCF-7 cells were grown in Eagle's minimum essential medium containing L-glutamine, $2.2 \mathrm{~g} / 1 \mathrm{NaHCO}_{3}, 110 \mathrm{mg} / \mathrm{l}$ sodium pyruvate (Sigma, München, FRG), and $10 \%$.FCS. T-47-D was cultivated in RPMI-1640 medium containing L-glutamine, $2.0 \mathrm{~g} / 1$ $\mathrm{NaHCO}_{3}$ and $10 \% \mathrm{FCS}$. The culture medium was supplemented with $10 \mathrm{mg} / \mathrm{l}$ bovine insulin (Sigma, München, FRG). The ZR-75-1 cell line was maintained in RPMI-1640 medium with L-glutamine, $2.0 \mathrm{~g} / 1 \mathrm{NaHCO}, 10 \% \mathrm{FCS}$ and $11.6 \mathrm{mg} / 1$ tylosin.

The hormone-independent $\mathrm{MXT}^{-}$and $\mathrm{MXT}^{ \pm}$sublines were oestrogen-receptor-negative. Cells were maintained in RPMI-1640 medium containing an additional $0.6 \mathrm{~g} / 1 \mathrm{~L}$-glutamine (i.e. $0.9 \mathrm{~g} / \mathrm{l}$ ), $2.0 \mathrm{~g} / 1 \mathrm{NaHCO}_{3}$ and $10 \% \mathrm{FCS}$.

The hormone-sensitive and oestrogen-receptor-positive $\mathrm{MXT}^{+}$ variant required $100 \mathrm{ng} / \mathrm{l}$ oestradiol (Sigma, München, FRG) supplementation of the same basic medium formulation. All culture media contained $50 \mathrm{mg} / \mathrm{l}$ gentamycin (Sebio, Walchsing, FRG).

The cells were serially passaged following trypsinization using trypsin $(0.05 \%)$ /EDTA $(0.02 \%)$ (Bochringer, Mannheim, FRG) and cultured in a water-saturated atmosphere of $95 \%$ air and $5 \%$ carbon dioxide at $37^{\circ} \mathrm{C}$ in $75-\mathrm{cm}^{2}$ culture flasks (Costar, Tecnomara, Fernwald, FRG).

Drugs. Hyaluronidase from bovine testis was kindly provided in highly purified, lyophilized form as Neopermease in vials containing $200000 \mathrm{IU}$ (specific activity approx. $50000 \mathrm{IU} / \mathrm{mg}$ protein) with carrier gelatin $(25 \mathrm{mg})$ by Sanabo Gesellschaft m.b.H. (Vienna, Austria). The enzyme was dissolved in an appropriate volume of deionized water immediately before use.

Adriamycin (doxorubicin hydrochloride) was purchased from Sigma (München, FRG). For the in vitro chemosensitivity assay the drug was dissolved in $70 \%(\mathrm{v} / \mathrm{v})$ ethanol; for in vivo testing a solution in $0.9 \% \mathrm{NaCl}$ was used.

Chemosensitivity assay. A standardized kinetic microassay based on crystal violet staining was used. The technical details of the procedure and the method of evaluating drug action have been discussed recently (Bernhardt et al. 1992). In brief: cells were seeded $(100 \mu \mathrm{l} /$ well) in 96-well flat-bottomed microtitration plates (Costar,
Tecnomara, Fernwald, FRG) at an appropriate density of about 15 cells/microscopic field (magnification $320 \times$ ). After 42-48 h (ZR75-1: $72 \mathrm{~h}$ ) the culture medium was removed by suction and replaced by medium $(200 \mu \mathrm{l} / \mathrm{well}$ ) containing drug or pure vehicle (gelatin carrier dissolved in water; Adriamycin in 70\% ethanol). Drugs were added as a 1000 -fold concentrated stock solution. On every plate two rows $(n=16)$ served as controls and two rows $(n=16)$ were used per drug concentration. After various times of incubation the cells were fixed with glutaraldehyde and stored in the refrigerator. At the end of the experiment all plates were stained with crystal violet simultaneously. Absorbance was measured at $578 \mathrm{~nm}$ using a Biotek 309 Autoreader (Tecnomara, Fernwald, FRG). Processing procedure, data analysis and evaluation were performed as described (Reile et al. 1990; Bernhardt et al. 1992). Results are presented as plots of absorbance or corrected $\mathrm{T} / \mathrm{C}$ values versus time of incubation according to $\mathrm{T} / \mathrm{C}_{\text {corr }}(\%)=100 \times\left(T-C_{0}\right) /\left(C-C_{0}\right)$, where $T$ is the absorbance of the treated cells, $C$ the absorbance of the controls, and $C_{0}$ the absorbance of the cells at the time when drug was added $(t=0)$.

In vivo testing on the $M X T M 3.2$ mammary carcinoma. Animals were housed in Macrolon cages (size III, Ehret, Memmingen, FRG) at an ambient temperature of $21^{\circ} \mathrm{C}$ with a $12-\mathrm{h}$ light/dark cycle. Mice were fed with laboratory animal chow (H-1003, Alma, Kempten, FRG) and water was provided ad libitum. The ovary-dependent MXT M3.2 tumour was propagated by s.c. implantation of about $2-\mathrm{mm}^{3}$ tumour pieces into the right thoracal mammary fat pad of intact 8-week-old female $\mathrm{B}^{2} \mathrm{D}_{2} \mathrm{~F}_{1}$ mice (Charles River Wiga, Sulzfeld, FRG). The detailed testing procedure and the characteristics of this tumour model have been described elsewhere (Spruß et al. 1991, 1992). Briefly, tumours were implanted subcutaneously into the right flank of intact females on day 0 , and the animals were randomly assigned to groups of ten.

In the monotherapy experiment treatment was started on day 5 by injecting $1.2 \times 10^{6} \mathrm{IU} / \mathrm{kg}$ hyaluronidase and vehicle (gelatin carrier) s.c. into the right flank, near to the site of transplantation.

In the combination therapy experiment hyaluronidase $\left(1.2 \times 10^{6} \mathrm{IU} / \mathrm{kg}\right.$, weekly) was administered peritumourally, $4 \mathrm{~h}$ prior to the i.p. injection of Adriamycin $(0.2 \mathrm{mg} / \mathrm{kg}$, three times a week). For positive control, one group was ovariectomised 1 day after tumour transplantation (day 1).

Tumour diameters were measured with a caliper. Tumour areas were calculated as the product of two perpendicular diameters, one measured across the greatest width of the tumour.

Statistics. Significance levels of the in vitro data were calculated according to the $t_{\mathrm{HET}}$-test (Sokal and Rohlf 1987a). The significance levels of the median tumour areas after combination therapy (in vivo experiment) were determined according to the Mann-Whitney $U$-test (Sokal and Rohlf 1987 b).

\section{Results}

\section{Effect of hyaluronidase on the cell proliferation of breast cancer cells in vitro}

Increasing concentrations of hyaluronidase were tested on various murine and human breast cancer cell lines. Monotherapy with 2500, 5000, and $10000 \mathrm{IU} / 1$ hyaluronidase had no effect on the growth kinetics of the murine $\mathrm{MXT}^{ \pm}$mammary carcinoma. In accordance with this observation, $10000 \mathrm{IU} / 1$ enzyme did not affect cell proliferation of the $\mathrm{MXT}^{-}$variant. Increasing doses of hyaluronidase $(10000,20000,30000,40000$, and $50000 \mathrm{IU} / 1)$ were not inhibitory to the oestrogen-receptor-positive $\mathrm{MXT}^{+}$subline. Further dosage escalation up to $80000 \mathrm{IU} / 1$ was ineffective against the human hormonesensitive MCF-7, ZR-75-1, and T-47-D cell lines. 
High-dose hyaluronidase treatment of the MXT M3.2 mammary carcinoma of the $B 6 D 2 F_{1}$ mouse

Tumour-bearing animals were treated with $1.2 \times 10^{6} \mathrm{IU} /$ $\mathrm{kg}$ hyaluronidase beginning on day 5 after tumour transplantation. The enzyme was injected s.c. near to the site of tumour implantation. Figure 1 shows that administration of five single doses (on days $5,12,19,26$, and 33) did not inhibit tumour growth, whereas typical suppression of tumour proliferation by ovariectomy was observed in this highly reproducible, ovary-dependent breast cancer model. There was no difference in tumour growth when gelatin carrier was used instead of the usual $\mathrm{NaCl}$ control (Spruß et al. 1991). The five "megadoses" of hyaluronidase were very well tolerated, as indicated by the weight gain of the animals during the course of the experiment (Fig. 1, inset). At the end of the experiment, no signs of toxic side-effects caused by hyaluronidase treatment could be detected by routine dissection of the animals.

\section{Combination therapy with high-dose hyaluronidase and Adriamycin}

In vitro testing on $M X T^{+}$breast cancer cells. The effects of Adriamycin monotherapy $(50 \mathrm{n} M)$ and combination therapy ( $50 \mathrm{n} M$ Adriamycin with $50000 \mathrm{IU} / 1$ hyaluronidase) on cell proliferation using the kinetic crystal violet chemosensitivity assay were compared. The results of this experiment are summarized in Fig. 2. A slight, but significant $(P=0.03)$ increase in the antitumour activity of Adriamycin by the addition of a concentration of hyaluronidase inactive per se was observed.

\section{In vivo enhancement of Adriamycin activity by combination with high-dose hyaluronidase}

As an extension of the in vitro combination therapy experiments, the corresponding ovary-dependent MXT M3.2 mammary tumour model of the $\mathrm{B} 6 \mathrm{D} 2 \mathrm{~F}_{1}$ mouse was used. Drug treatment started on day 19 after tumour transplantation, whereas the positive control group was ovariectomized on day 1 .

Hyaluronidase $\left(1.2 \times 10^{6} \mathrm{IU} / \mathrm{kg}\right)$ was injected peritumourally $4 \mathrm{~h}$ prior to the i.p. injection of nontoxic doses of Adriamycin $(0.2 \mathrm{mg} / \mathrm{kg})$ on days $19,26,33$, and 40 . From day 19, Adriamycin was administered three times a week. Tumour growth was only slightly delayed by Adriamycin monotherapy, whereas ovariectomy was highly effective (Fig. 3). Interestingly, there was a dramatic augmentation of Adriamycin activity by hyaluronidase pretreatment $(P<0.05)$ (Fig. 3), despite the relatively late beginning of treatment. As demonstrated above (cf. Fig. 1), monotherapy with hyaluronidase was ineffective at the same concentration. Remarkably, the toxicity of Adriamycin was not enhanced by hyaluronidase pretreatment (cf. Fig. 3, inset).

\section{Discussion}

Large amounts of hyaluronic acid are present in several types of tumours, including murine and human breast cancer (Angello et al. 1980; Knudson et al. 1984 a; Knud-

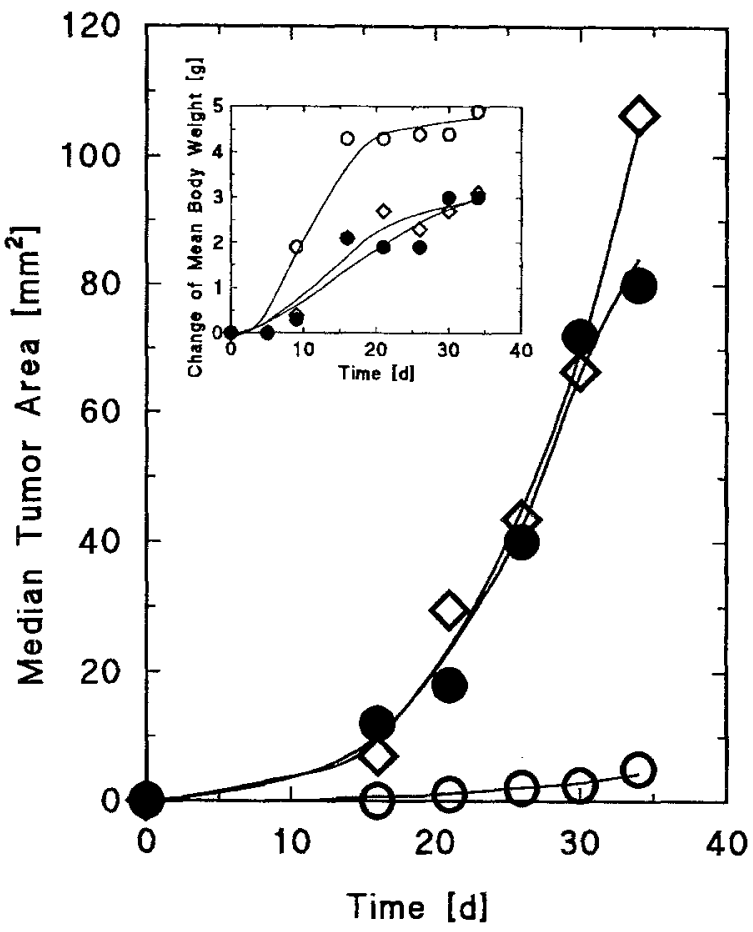

Fig. 1. Effect of high-dose hyaluronidase therapy of the MXT M3.2 mammary carcinoma of the $\mathrm{B} 6 \mathrm{D} 2 \mathrm{~F}_{1}$ mouse. Hyaluronidase $\left(1.2 \times 10^{6} \mathrm{IU} / \mathrm{kg}\right)$ was injected peritumourally on days $5,12,19,26$, and 33. Inset: change of mean body weight during the course of treatment. - Control (gelatin carrier); $\diamond$, treatment group; O, ovariectomy control

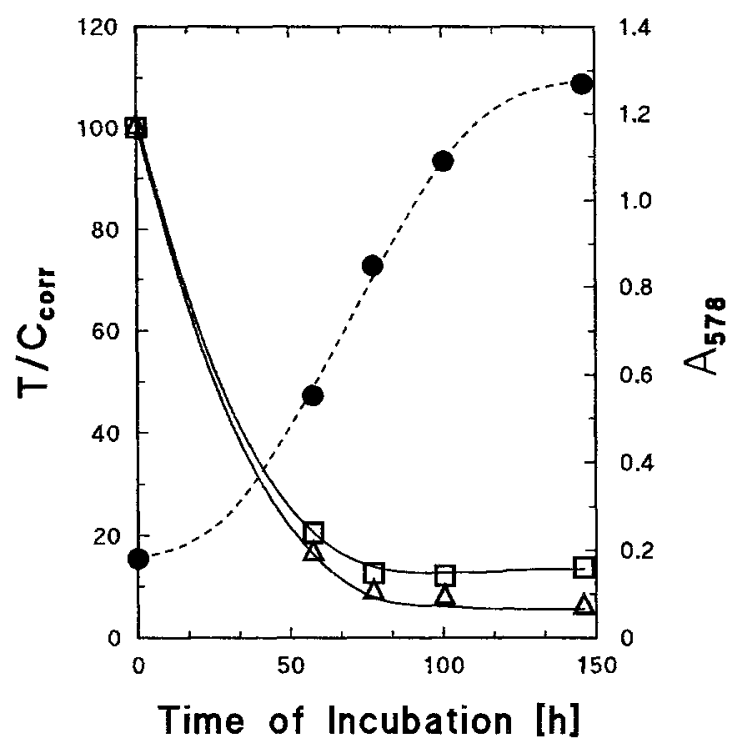

Fig. 2. Combination therapy of $\mathrm{MXT}^{+}$breast cancer cells with hyaluronidase and Adriamycin in vitro. Growth curve of the gelatin carrier control (O). Plot of corrected $\mathrm{T} / \mathrm{C}$ values versus time: $\square, 50 \mathrm{n} M$ Adriamycin; $\triangle$, combination of $50 \mathrm{n} M$ Adriamycin and $50000 \mathrm{IU} / 1$ hyaluronidase. At the end of the experiment the observed difference between Adriamycin monotherapy and combination therapy was significant at the $P=0.03$ level ( $t_{\mathrm{HET}}$-test)

son et al. 1989; Marotta et al. 1985). Elevated hyaluronate concentrations are not only an in vivo phenomenon; isolated mammary tumour cells in culture have also been reported to produce glycosaminoglycan (Chandrasekaran and Davidson 1979, Knudson et al. 1989), al- 


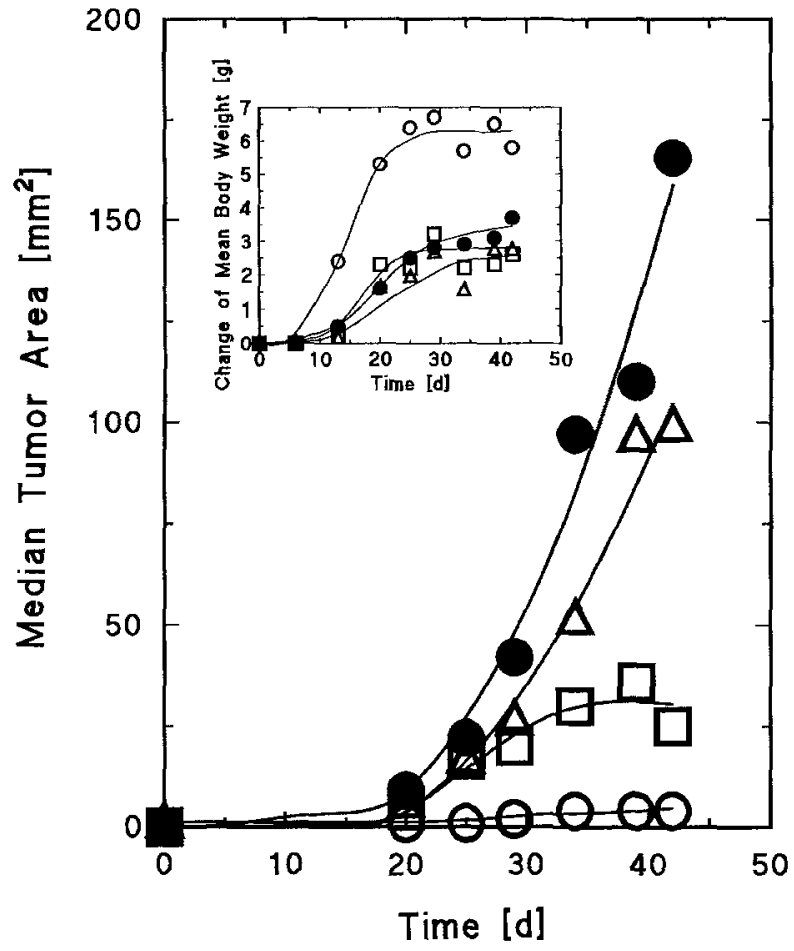

Fig. 3. Combination therapy of the MXT M3.2 mammary carcinoma of the $\mathrm{B} 6 \mathrm{D} 2 \mathrm{~F}_{1}$ mouse with high-dose hyaluronidase and Adriamycin. Hyaluronidase $\left(1.2 \times 10^{6} \mathrm{IU} / \mathrm{kg}\right)$ was injected peritumourally, $4 \mathrm{~h}$ prior to the i.p. application of $0.2 \mathrm{mg} / \mathrm{kg}$ Adriamycin. Hyaluronidase was administered on days $19,26,33$, and 40 , whereas Adriamycin was administered three times a week, starting on day 19. Inset: change of mean body weight during the course of treatment. @, Gelatin carrier control; $\Delta$, Adriamycin monotherapy; $\square$, combination therapy with hyaluronidase and Adriamycin; $O$, ovariectomy control. At the end of the experiment the observed difference in median tumour area after Adriamycin monotherapy and combination therapy was significant at the $P<0.05$ level $(U$-test)

though frequently in very small amounts. When added to cultured cells, hyaluronate can influence mitosis, cell differentiation and proliferation in a complex way. Hyaluronic acid is considered to inhibit differentiation and to promote cell proliferation instead (Decker et al. 1989). Prehm (1990) discussed the observation that high-molecular-mass hyaluronate inhibits cell growth, whereas small fragments are stimulatory. In addition, it is known that hyaluronidase treatment of living cells stimulates the synthesis of hyaluronic acid (Philipson et al. 1985; Larnier et al. 1989), which might result in a feed back inhibition of cell proliferation. Our experiments using three murine and three human breast cancer cell lines clearly demonstrate that cell proliferation was not inhibited by addition of increasing concentrations (from 2500 to $80000 \mathrm{IU} / 1$ ) of bovine testicular hyaluronidase to the culture medium. From these data (the missing inhibition of cell proliferation) there was no evidence for a direct dose-dependent effect of hyaluronidase on cell-surface constituents such as has been speculated by Scheithauer et al. (1988) who had measured $\left[{ }^{14} \mathrm{C}\right]$ glucose metabolism of gastrointestinal carcinoma cell lines as a function of treatment with hyaluronidase and cytostatics. Since not all tumour cells synthesize hyaluronate, and we have not checked the hyaluronic acid content of our mammary carcinoma cell lines, we can not rule out the possibility that in these cell lines there is no glycosaminoglycan expression.

However, there seemed to be a slight tendency towards growth stimulation of the $\mathrm{MXT}^{+}$and the T-47-D cell line. As mentioned above, this could be explained by the release of low-molecular-mass oligosaccharides from cell-associated hyaluronic acid after hyaluronidase cleavage.

Although hyaluronidase itself was ineffective in vitro, we decided to investigate the effect of high-dose hyaluronidase therapy on the MXT M3.2 mammary carcinoma in vivo, since often there ist a discrepancy between the large amount of hyaluronic acid found in solid tumours, and the only small amounts of polysaccharide produced in cell culture. Coculture experiments of tumour cells with fibroblasts indicate that the tumour cells stimulate the synthesis of hyaluronic acid by fibroblasts (Knudson et al. 1984b) via a membrane-bound (Knudson and Toole 1988) or a secreted stimulatory factor (Larnier et al. 1989; Decker et al. 1989). Thus, interactions between tumour cells and fibroblasts of the host seem to be responsible for the high hyaluronate concentration found in tumours. Forrester and Wilkinson (1981) reported that concentrated solutions of hyaluronan inhibited the migration of certain types of leukocytes, particularly neutrophils. Inhibition of leukocyte locomotion in combination with the formation of hyaluronidase-labile coats ("halos") around cancer cells, induced in mixed culture with peripheral blood mononuclear cells (Zänker et al. 1982; Gately et al. 1984), might confer "immunoprotection" on the tumour in vivo. In addition, hyaluronate has been demonstrated to be unique among the glycosaminoglycans in that it can stimulate or inhibit angiogenesis directly, depending on its size. Whereas hyaluronate-rich stroma inhibits blood vessel formation, low-molecularmass oligosaccharides, as formed by hyaluronidase hydrolysis, stimulate angiogenesis in chick embryos (West and Kumar 1989).

Unfortunately, there was no evidence for the implication of the discussed mechanisms above in the proliferation of the MXT M3.2 mammary tumour of the B6D2F $F_{1}$ mouse. As shown in Fig. 1, high-dose peritumoural hyaluronidase treatment failed to inhibit tumour growth. However, this experiment proved that hyaluronidase is excellently tolerated, even when administered at "megadoses". Our findings are consistent with the "noeffect level" of hyaluronidase in mice being $1.5 \times 10^{6} \mathrm{IU} /$ $\mathrm{kg}$ for a single i.v. injection (Baumgartner and Moritz 1988).

Some clinical observations suggest that hyaluronidase preinfusion potentiates the effectiveness of chemotherapy (Baumgartner 1987, 1988; Baumgartner and Moritz 1988). The results of our experiments, comparing the antitumour activity of Adriamycin itself with the activity of a combination of Adriamycin and hyaluronidase against breat cancer in vitro and in vivo, support the clinical data. Figure 2 shows that the cytotoxic effect of Adriamycin against the $\mathrm{MXT}^{+}$cell line was enhanced in the presence of hyaluronidase. The augmentation of Adriamycin cytotoxicity is consistent with the data re- 
ported by Lehnert et al. (1989) who could show, in the clonogenic assay, that the activity of doxorubicin on the murine P 388 leukemia cell line was enhanced in the presence of hyaluronidase.

The enhancement of Adriamycin activity in combination with hyaluronidase was even more impressive in vivo (cf. Fig. 3). The most straightforward mechanism to explain this quantitative difference is the enzymatic degradation of the hyaluronate-enriched intercellular matrix in solid tumours. By generating hydrated intercellular space, hyaluronidase facilitates diffusion of Adriamycin. As a consequence, tumour growth is inhibited indirectly, by the improved availability of the chemotherapeutic.

In this study we could demonstrate that hyaluronidase, when administered at high doses, can principally potentiate the activity of Adriamycin against experimental breast cancer, without increasing toxic side-effects. Further work must prove whether potentiation of antineoplastic activity will still be maintained after the systemic administration of lower doses of hyaluronidase. Nevertheless, if the results of these future studies were to be negative, high-dose hyaluronidase, in combination with chemotherapeutics, may still lead to an improvement of the outcome of isolated limb perfusion, practiced in the therapy of malignant melanoma.

Acknowledgements. We thank P. Pistor, O. Baumann, and F. Wiesenmayer for their excellent technical help. Thanks are due to the Sandoz Gesellschaft m.b.H. (Vienna, Austria) for financial support.

\section{References}

Angello JC, Anderson LW, Hosick, HL (1980) Cell surface glycosaminoglycans of tumorigenic and non-tumorigenic mouse mammary epithelial cells. In Vitro 16:210

Angello JC, Hosick HL, Anderson LW (1982) Glycosaminoglycan synthesis by a cell line (C1-S1) established from a preneoplastic mouse mammary outgrowth. Cancer Res 42:4975-4978

Baumgartner G (1987) Hyaluronidase in der Therapie maligner Erkrankungen. Wien Klin Wochenschr [Suppl] 174:1-22

Baumgartner G (ed) 1988 Hyaluronidase - eine wirksame Substanz in der Behandlung maligner Erkrankungen? Referate gehalten im Rahmen der 6 . Arbeitstagung des Ludwig Boltzmann-Institutes für Hämatologie und Leukämieforschung, Wien (11. bis 13. Februar 1988). Wien Klin Wochenschr [Suppl] 178:1-23

Baumgartner G, Moritz A (eds) (1988) Hyaluronidase: Anwendung in der Onkologie. Springer-Verlag, Wien Berlin Heidelberg New York

Baumgartner G, Fortelny A, Zänker KS, Kroczek R (1988) Phase I study in chemoresistant loco-regional malignant disease with hyaluronidase. Reg Cancer Treat 1:55-58

Beckenlehner K (1991) Etablierung und Charakterisierung muriner Mammacarcinom-Zellinien (MXT) zur vergleichenden Prüfung neuer Antitumorwirkstoffe. Diplomarbeit, Universität Regensburg

Bernhardt G, Reile H, Birnböck H, Spruß T, Schönenberger H (1992) Standardized kinetic microassay to quantify differential chemosensitivity on the basis of proliferative activity. J Cancer Res Clin Oncol 118:35-43

Chandrasekaran EV, Davidson E (1979) Glycosaminoglycans of normal and malignant cultured human mammary cells. Cancer Res 39:870-880
Cooper EH, Forbes MA (1988) Serum hyaluronic acid levels in cancer. Br J Cancer 58:668-669

Dahl IM, Laurent TC (1988) Concentration of hyaluronan in the serum of untreated cancer patients with special reference to patients with mesothelioma. Cancer 62:326-330

Dahl IM, Solheim ØP, Erikstein B, Müller E (1989) A longitudinal study of the hyaluronan level in the serum of patients with malignant mesothelioma under treatment. Cancer 64:68-73

Decker M, Chiu ES, Dollbaum C, Moiin A, Hall J, Spendlove R, Longaker MT, Stern R (1989) Hyaluronic acid-stimulating activity in sera from the bovine fetus and from breast cancer patients. Cancer Res 49:3499-3505

Delpech B, Bertrand P, Maingonnat C (1985) Immunoenzymoassay of the hyaluronic acid-hyaluronectin interaction: application to the detection of hyaluronic acid in serum of normal subjects and cancer patients. Anal Biochem 149:555-565

Forrester JV, Wilkinson PC (1981) Inhibition of leukocyte locomotion by hyaluronic acid. J Cell Sci 48:315-331

Frebourg T, Lerebours G, Delpech B, Benhamou D, Bertrand P, Maingonnat C, Boutin C, Nouvet G (1987) Serum hyaluronate in malignant pleural mesothelioma. Cancer 59:2104-2107

Gately CL, Muul LM, Greenwood MA, Papazoglou S, Dick SJ, Kornblith PL, Smith BH, Gately MK (1984) In vitro studies on the cell-mediated immune response to human brain tumors: II. Leukocyte-induced coats of glycosaminoglycan increase the resistance of glioma cells to cellular immune attack. J Immunol $133: 3387-3395$

Hay, RJ (1988) The seed stock concept and quality control for cell lines. Anal Biochem 171:225-237

Kimata K, Honma Y, Okayama M, Oguri K, Hozumi M, Suzuki $S$ (1983) Increased synthesis of hyaluronic acid by mouse mammary carcinoma cell variants with high metastatic potential. Cancer Res 43:1347-1354

Knudson W, Toole BP (1988) Membrane association of the hyaluronate stimulatory factor from LX-1 human lung carcinoma cells. J Cell Biochem 38:165-177

Knudson W, Biswas C, Toole BP (1984 a) Stimulation of glycosaminoglycan production in murine tumours. J Cell Biochem 25:183196

Knudson W, Biswas C, Toole BP (1984 b) Interactions between human tumor cells and fibroblasts stimulate hyaluronate synthesis. Proc Natl Acad Sci USA 81:6767-6771

Knudson W, Biswas C, Li XQ, Nemec RE, Toole BP (1989) The role and regulation of tumour-associated hyaluronan. Ciba Found Symp 143:150-169

Kohno N, Ohnuma T, Truog P, Biller H, Holland JF (1988) Effects of hyaluronidase on doxorubicin penetration into multicellular tumour spheroids and cell lethality. Proc Am Assoc Cancer Res 29: abstract no. 1329

Larnier C, Kerneur C, Robert L, Moczar M (1989) Effect of testicular hyaluronidase on hyaluronate synthesis by human skin fibroblasts in culture. Biochim Biophys Acta 1014:145-152

Lehnert M, Liu R, Salmon SE (1989) Hyaluronidase (HYase) enhances drug toxicity on clusters/colonies of P-388 cells in clonogenic assay. Proc Am Assoc Cancer Res 30: abstract no. 2286

Liu R, Cox J, Salmon S (1987) Hyaluronidase enhances the in vitro cytotoxicity of 5-fluorouracil. In Vitro 23: abstract no. 10

Marotta M, Vecchione R, Martino G, D'Armiento FP, De Cesare M, Rosati P (1985) Glycosaminoglycan-enriched extracellular matrix surrounds intraductal carcinoma of human breast: histochemical study. Appl Pathol 3:179-185

Pawlowski A, Haberman HF, Menon IA (1979) The effects of hyaluronidase upon tumor formation in $\mathrm{balb} / \mathrm{c}$ mice painted with 7,12-dimethylbenz(a)anthracene. Int J Cancer 23:105-109

Pettersson T, Fröscth B, Riska H, Klockars M (1988) Concentration of hyaluronic acid in pleural fluid as a diagnostic aid for malignant mesothelioma. Chest 94:1037-1039

Philipson LH, Westley J, Schwartz N (1985) Effect of hyaluronidase treatment of intact cells on hyaluronate synthetase activity. Biochemistry 24:7899-7906 
Prehm P (1990) Release of hyaluronate from eukaryotic cells. Biochem J 267:185-189

Reile H, Birnböck H, Bernhardt G, Spruß T, Schönenberger H (1990) Computerized determination of growth kinetic curves and doubling times from cells in microculture. Anal Biochem 187:262-267

Sargent NSE, Price JE, Tarin D (1983) Effect of enzymatic removal of cell surface constituents on metastatic colonisation potential of mouse mammary tumour cells. Br J Cancer 48:569-577

Scheithauer W, Temsch EM, Stefeneli T, Lathan B (1988) Ergebnisse experimenteller Untersuchungen des zytostatikamodulierenden Effektes von Hyaluronidase bei gastrointestinalen Karzinomzellinien. Wien Klin Wochenschr [Suppl] 178:12-13

Seipelt H, Kohlheb O (1967) Die Mitoseaktivität des Ehrlich-Ascites-Carcinoms der weißen Maus nach intraperitonealen Hyaluronidase-Gaben. Arzneim Forsch 17:513-515

Sokal RR, Rohlf FJ (1987 a) Introduction to biostatistics, 2nd edn. Freeman, New York, p 106

Sokal RR, Rohlf FJ (1987 b) Introduction to biostatistics, 2nd edn. Freeman, New York, p 220
Spruß T, Bernhardt G, Schickaneder E, Schönenberger H (1991) Different response of murine and human mammary tumour models to a series of diastereoisomeric [1,2-bis(difluorophenyl)ethylenediamine]dichloroplatinum(II) complexes. J Cancer Res Clin Oncol 117:435-443

Spruß T, Bernhardt G, Schönenberger H, Engel J (1992) Antitumour activity of miltefosine alone and after combination with platinum complexes on MXT mouse mammary carcinoma models. J Cancer Res Clin Oncol (in press)

Stern M, Longaker MT, Adzick NS, Harrison MR, Stern R (1991) Hyaluronidase levels in urine from Wilms' tumor patients. J Natl Cancer Inst 83:1569-1574

West DC, Kumar S (1989) The effect of hyaluronate and its oligosaccharides on endothelial cell proliferation and monolayer integrity. Exp Cell Res 183:179-196

Wu AH, Parker OS, Ford L (1984) Hyperviscosity caused by hyaluronic acid in serum in a case of Wilms' tumor. Clin Chem 30:914-916

Zänker KS, Trappe A, Blümel G (1982) In-vitro resistance of cloned human glioma cells to natural killer activity of allogeneic peripheral lymphocytes. Br J Cancer 46:617-624 